\title{
Ozone fumigation of Norway spruce at timberline
}

\author{
W.M. Havranek ${ }^{1}$, G. Wieser ${ }^{1}$ and M. Bodner ${ }^{2}$ \\ 1 Forstliche Bundesversuchsanstalt, AuBenstelle für subalpine Waldforschung, Innsbruck, and \\ 2 Institut für Botanik der Universität Innsbruck, Austria
}

\section{Introduction}

Ozone is thought to be involved in forest decline (Bucher, 1986; Krause et al., 1986), especially at high altitudes, where increased $\mathrm{O}_{3}$ levels together with a fast increase in forest damage has been observed (Berichte Tiroler Landtag, 1985-1988). Many investigations on the impact of $\mathrm{O}_{3}$ on trees have been carried out under laboratory conditions, mainly with seedlings, but few in the field (Smidt, 1978; Pye, 1988). Experimental data of effects of $\mathrm{O}_{3}$ on adult trees under field conditions are rare (Coyne and Bingham, 1982) or lacking altogether as for instance for the timberline region. Therefore it seemed to be of interest to fumigate an adult spruce tree with various $\mathrm{O}_{3}$ concen- trations and to examine the effects of $\mathrm{O}_{3}$ on gas exchange and chlorophyll fluorescence, both known to be indicators of latent or hidden $\mathrm{O}_{3}$ injury.

\section{Materials and Methods}

For this study, a $60 \mathrm{yr}$ old spruce tree (Picea abies (L.) Karst.) near the Klimahaus research station on Mt. Patscherkofel (1920 m a.s.l.) near Innsbruck was selected. For each treatment, 6 similar twigs were enclosed in plexiglass chambers, where the air was exchanged 3-4 times per minute. $\mathrm{O}_{3}$ treatments were as follows: control (charcoal-filtered air), ambient air, ambient air $+38 \mathrm{ppb} \mathrm{O}_{3}(1987)$ and $120 \mathrm{ppb}$ $\mathrm{O}_{3}$ (1986), respectively. The twigs were left in the fumigation chambers for one full growing season (July to September). Monthly means of

Table I. Monthly means of $\mathrm{O}_{3}$ concentration, air temperature, relative humidity and sums of precipitation at the research site on Mt. Patscherkofel.

\begin{tabular}{|c|c|c|c|c|c|c|c|c|}
\hline & \multicolumn{4}{|l|}{1986} & \multicolumn{4}{|l|}{1987} \\
\hline & $O_{3}(p p b)$ & Temp. $\left({ }^{\circ} \mathrm{C}\right)$ & R.H. (\%) & $P(m m)$ & $O_{3}(p p b)$ & Temp. $\left({ }^{\circ} \mathrm{C}\right)$ & R.H. (\%) & $P(m m)$ \\
\hline July & 72 & 8.3 & 68 & 85 & 74 & 10.2 & 92 & 189 \\
\hline Aug. & $6 \overline{6}$ & 8.8 & 68 & 199 & 62 & 7.5 & 80 & 129 \\
\hline Sept. & 48 & 6.9 & 61 & 52 & 57 & 9.8 & 71 & 75 \\
\hline
\end{tabular}


Table II. Stomatal conductance (mmol $\mathrm{H}_{2} \mathrm{O} \cdot \mathrm{m}^{-2} \cdot \mathrm{s}^{-1}$ ) of current and last year's needles in 1986 and 1987.

\begin{tabular}{llll}
\hline Treatment & Fumigation & $\begin{array}{l}\text { Fumigation } \\
12 w k\end{array}$ & Needles \\
\hline 1986 & $4 w k$ & & \\
$\quad$ control & $27.5 \pm 5.1$ & $37.3 \pm 7.9$ & current \\
ambient air & $29.9 \pm 8.1$ & $46.9 \pm 9.6$ & \\
$120 \mathrm{ppb} \mathrm{O}_{3}$ & $39.7 \pm 10.7 \mathrm{a}$ & $42.1 \pm 12.7$ & \\
1987 & $8 w k$ & & current \\
control & $45.9 \pm 7.7$ & $54.6 \pm 8.0$ & \\
ambient air & $52.9 \pm 13.1$ & $54.0 \pm 3.8$ & last yr's \\
ambient $+38 \mathrm{ppb}$ & $49.1 \pm 10.2$ & $55.3 \pm 9.3$ & \\
& & $34.3 \pm 7.0$ & \\
control & - & $42.0 \pm 19.9$ & \\
ambient air & - & $38.2 \pm 10.1$ & \\
\hline ambient $+38 \mathrm{ppb}$ & - & &
\end{tabular}

a Statistically different from control: $P<0.05$.

$\mathrm{O}_{3}$, air temperature, relative humidity and sums of precipitation for 1986 and 1987 are given in Table I.

$\mathrm{O}_{3}$ was produced with a UV-lamp (Osram $\mathrm{HNS}-\mathrm{UOZ}$ ) and $\mathrm{O}_{3}$ concentrations in the chambers were checked daily with an ozone meter (Monitor Labs Mod. 8810). All gas exchange measurements were made in ambient air with a thermoelectricaliy controlled Minicuvette System (Walz, Effeltrich, FRG). Measurements were taken at light saturation, leaf temperatures of $21^{\circ} \mathrm{C}(1986)$ or $18^{\circ} \mathrm{C}(1987)$ and at a relative vapor pressure deficit of $10.6 \mathrm{~Pa} / \mathrm{kPa}$.

Chlorophyll fluorescence of small twigs from all cuvettes (i.e., 6 replicates per treatment) was also measured in situ after predarkening with light tight bags in 1987 (23 September, during daylight hours). A pulse-modulation fluorometer (Pam 103, Walz, Effeltrich, FRG) was used, as described by Schreiber et al. (1986).

\section{Results and Discussion}

At the end of the fumigation period, all twigs looked healthy and there was no visible needle damage. However, $\mathrm{O}_{3}$ concentrations were high enough to alter gas exchange parameters.

\section{Stomatal conductance}

In no case investigated did $\mathrm{O}_{3}$ treatments reduce stomatal conductance to values lower than those of control twigs. On the contrary, low doses of $\mathrm{O}_{3}$ seemed to increase conductance at least temporarily. In 1986, a 4 wk fumigation with 120 ppb led to a statistically significant increase of conductance of $45 \%$ compared to $\mathrm{O}_{3}$-free controls, which disappeared after 12 wk of fumigation (Table II). Under the 1987 conditions, all treatments resulted in similar stomatal conductance. A stomatal behavior similar to that observed in 1986 was found by Keller and Häsler (1984) in spruce seedlings, where conductance was also higher and stomata reacted more sluggishly than in controls.

Chlorophyll fluorescence and net photosynthesis

After 8 wk of fumigation in 1987, all samples exhibited normal fluorescence transients. There were no significant differ- 


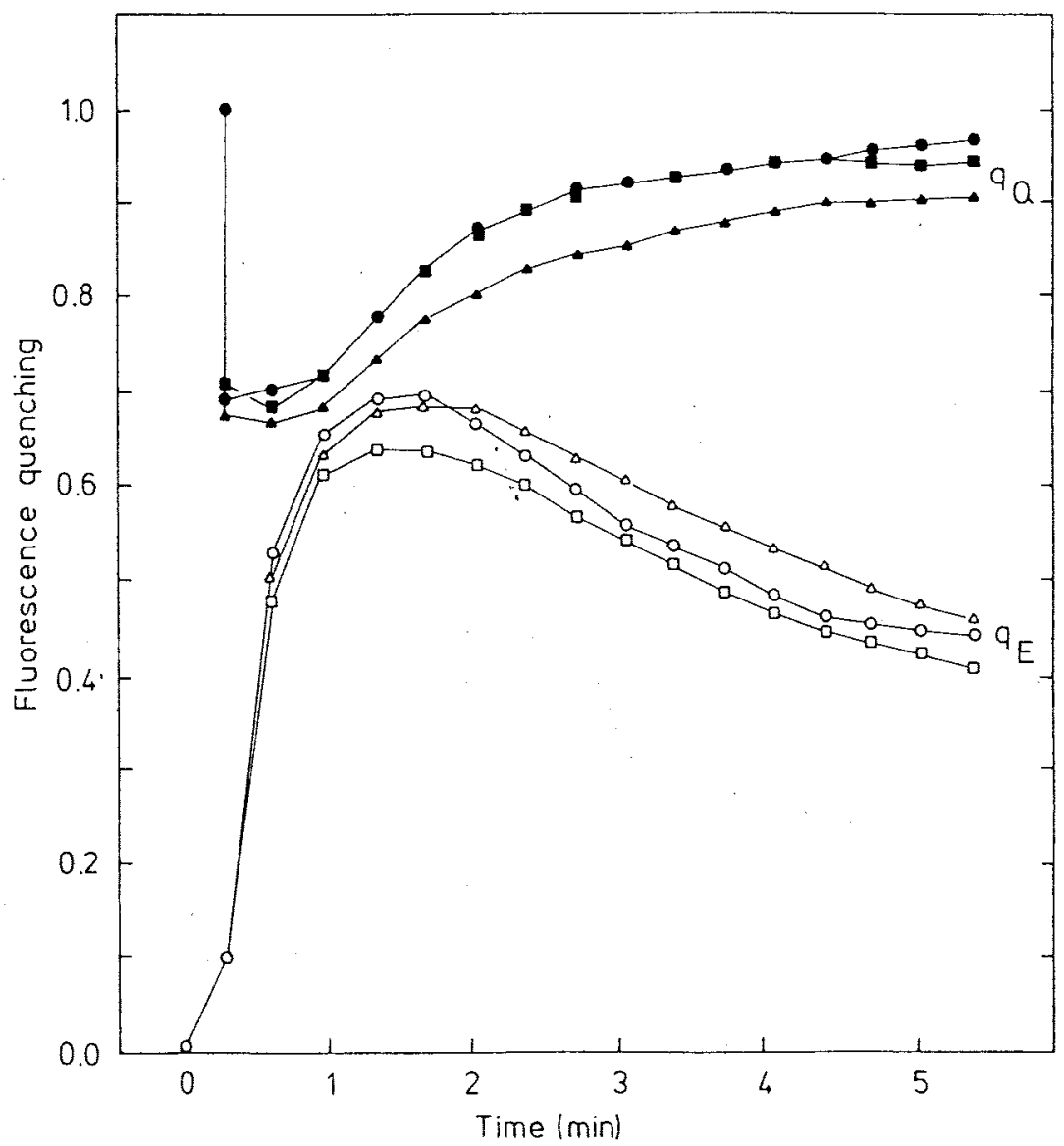

Fig. 1. Mean photochemical $\left(q_{Q}\right)$ and non-photochemical $\left(q_{E}\right)$ quenching coefficients of current needles of Norway spruce after 10 wk of fumigation with $0 \mathrm{ppb} \mathrm{O}_{3}(\mathrm{O})$, ambient air (mean $=64 \mathrm{ppb}, \square$ ), or ambient air $+38 \mathrm{ppb}=102$ $\mathrm{ppb} \mathrm{O}_{3}(\Delta) \cdot(n=6)$.

ences between the quenching coefficients (Fig. 1). The quotient $\left(F_{\max }-F_{0}\right) / F_{\max }$, which is a quantitative measure of the photochemical efficiency of photosystem II, was between 0.81 and 0.82 for all 3 treatments which is within the normal range for $\mathrm{C}_{3}$ plants (Björkman and Demmig, 1987).

At the same time, net photosynthesis was slightly but not significantly reduced in
$\mathrm{O}_{3}$-treated twigs. 12 wk of fumigation with ambient air also did not alter photosynthesis significantly compared to controls (Fig. 2). Elevated $\mathrm{O}_{3}$ levels, however, led to a significant decline in photosynthesis. Current year's needles fumigated with ambient air $+38 \mathrm{ppb} \mathrm{O}_{3}$ during daylight hours showed a decline of $10 \%$ and needles treated with $120 \mathrm{ppb} \mathrm{O}_{3}$ continuously showed a decrease of $30 \%$ when compared to controls. Last year's needles 
had reduced photosynthesis by about $5 \%$ after treatment with ambient air $+38 \mathrm{ppb}$ $\mathrm{O}_{3}$.

In discussing our results, we always have to keep in mind that this fumigation experiment was performed with only one tree. These results indicate that at timberline, where pollutants other than $\mathrm{O}_{3}$ were largely absent (Smidt, 1983), ozone concentrations of the ambient air did not alter gas exchange or chlorophyll fluorescence significantly within one vegetation period. Ozone concentrations slightly higher than that in ambient air, however, could stimulate stomatal opening leading to higher ozone uptake into the needles and reducing their photosynthetic rates in spite of the higher stomatal conductance.
Thus we conclude that $\mathrm{O}_{3}$ concentrations higher than $100 \mathrm{ppb}$ persisting for long time periods or a general further increase of $\mathrm{O}_{3}$ above present ambient levels would reduce photosynthesis in spruce, which, in combination with bad climatic or poor soil conditions, might result in a greater susceptibility to climatic and biotic damage.

\section{References}

Berichte an den Tiroler Landtag (1985-1988) Zustand der Tiroler Wälder. Amt der Tiroler Landesregierung, Landesforstinspektion Innsbruck

Björkman O. \& Demmig B. (1987) Photon yield of $\mathrm{O}_{2}$ and chlorophyll fluorescence characteris-

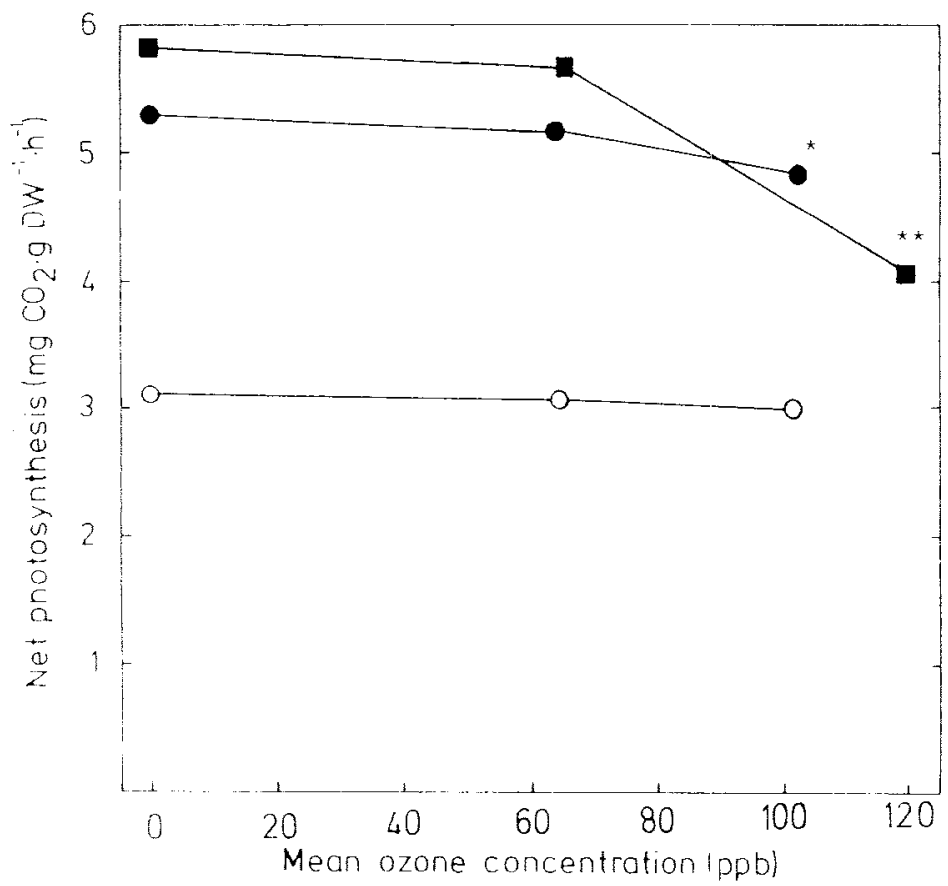

Fig. 2. Net photosynthesis of Norway spruce in response to mean ozone exposure after 12 wk of fumigation. a. current needles, investigated 1986; 0 : current needles, investigated 1987; O: last yr's needles, investigated 1987. "Statistically different from control: $P<0.05$, " Statistically different from control and ambient air: $P<0.02$. 
tics at $77 \mathrm{~K}$ among vascular plants of diverse origins. Planta 170, 489-504

Bucher J.B. (1986) Wirkungen von ozon auf waldbäume. XVIth IUFRO World Congr. Ljubtjana Yugoslavia, Sept. 1986 Proc. Div. 2, Vol. I, pp. 306-319

Coyne P.I. \& Bingham G.E. (1982) Variation in photosynthesis and stomatal conductance in an ozone-stressed ponderosa pine stand: light response. For. Sci. 28, 257-273

Keller T. \& Häsler R. (1984) The influence of a fall fumigation with ozone on the stomatal behavior of spruce and fir. Oecologia (Berlin) 64, 284-286

Krause G.H.M., Arndt U., Brandt C.J., Bucher J., Kenk G. \& Matzner E. (1986) Forest decline in Europe: development and possible causes. Water Air Soil Pollut. 31, 647-668

Pye J.M. (1988) Impact of ozone on the growth and yield of trees: a review. J. Environ. Qual. $17,347-360$

Schreiber U., Schliwa U. \& Bilger W. (1986) Continuous recording of photochemical and non-photochemical chlorophyll fluorescence quenching with a new type of modulation fluorometer. Photosynth. Res. 10, 51-62

Smidt S. (1978) Die wirkung von photochemischen oxydantien auf waldbäume. $Z$. Pflanzenkr. Pflanzenschutz 85, 689-702

Smidt S. (1983) Über das auftreten von ozon und stickstoffoxiden in waldgebieten Österreichs. Eur. J. For. Pathol. 13, 133-141 